\title{
An unusual cause of acute cholangitis
}

Endoscopic treatment can be challenging in patients presenting with biliary adverse events and a biliodigestive diversion. Multiples approaches have been described. In the past decade, an overall technical success of $80-86 \%$ [1-3] of enteroscopy-assisted endoscopic retrograde cholangiopancreatography (ERCP) has been described.

Herein, we report the original case of a 65 -year-old patient with sickle cell disease who was referred to our department for an unusual acute cholangitis. The patient had undergone biliodigestive anastomosis and Roux-en-Y jejunal loop 25 years ago because of refractory macrolithiasis of the common bile duct. Of note, patients with sickle cell disease are prone to developing biliary adverse events [4].

The patient presented with fever and jaundice. The abdominal computed tomography $(\mathrm{CT})$ scan confirmed the dilatation of the whole biliary tract and revealed a contiguous dilatation of the jejunal loop upstream of an impacted stone of $30 \mathrm{~mm}$ ( $\triangleright$ Fig.1). Once the absence of another cause of biliary obstruction was confirmed by magnetic resonance cholangiopancreatography (MRCP) [5], hybrid enteroscopy-assisted ERCP was proposed for the patient.

The enteroscopy was performed under general anesthesia, using a 3.2-mm working channel double-balloon enteroscope (EN-580T, Fujifilm, Tokyo, Japan). The push-and-pull technique was used to progress through the small bowel and the biliary loop was easily catheterized. Approximately $40 \mathrm{~cm}$ beyond the anastomosis, we identified a large biliary stone completely obstructing the lumen, impacted on a relative stenosis ( $\mathbf{F i g} . \mathbf{2}$ ). Lithotripsy was performed using 30-mm braided snare (Lariat; Life Partners Europe, Bagnolet, France) ( $\downarrow$ Video 1 ). After multiple passes, the stone was completely broken up and the obstruction
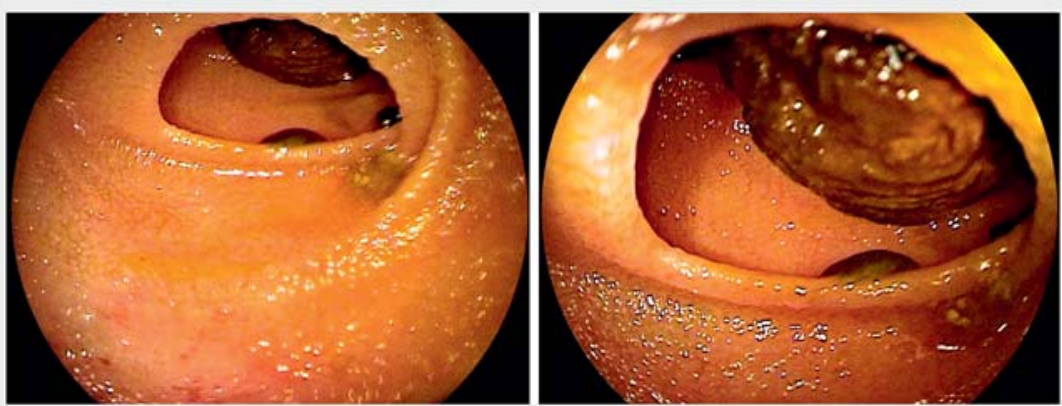

- Fig. 1 Digestive radiological exam revealed a contiguous dilatation of the biliary loop to the biliary tree upstream of a $35-\mathrm{mm}$ impacted stone. a Abdominal computed tomography scan. b Magnetic resonance cholangiopancreatography.
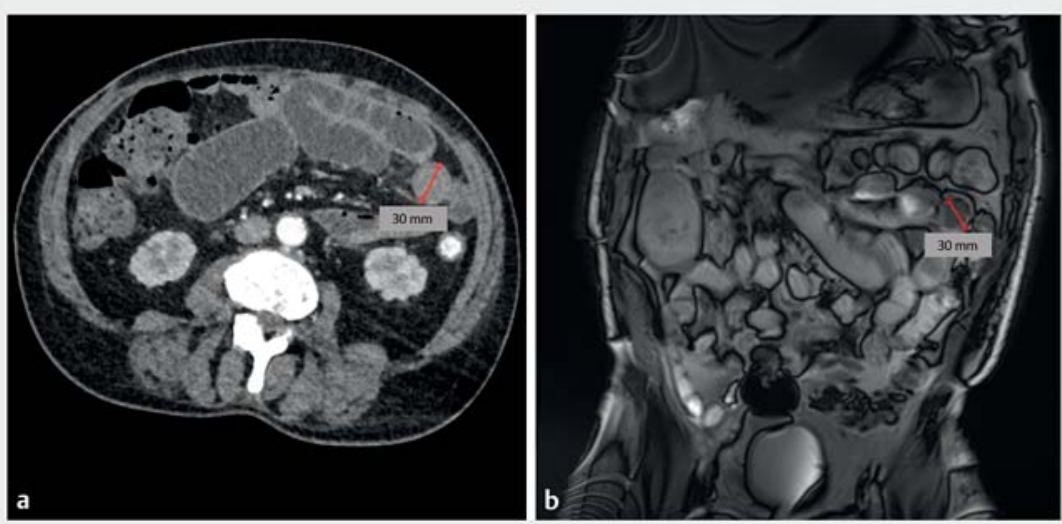

- Fig. 2 Endoscopic view of a large biliary stone $(30 \mathrm{~mm})$ obstructing the whole digestive lumen. Of note, the stone was impacted on a relative non-ulcerated stenosis.

eliminated. The patient recovered well and was discharged 3 days later. The abdominal CTscan performed 1 month later confirmed the absence of residual stones.

Endoscopy_UCTN_Code_TTT_1AR_2AH

\section{Competing interests}

The authors declare that they have no conflict of interest.

\section{The authors}

Guillaume Perrod Enrique Pérez-CuadradoRobles ${ }^{\top}$ Hedi Benosman, Hadrien Alric, Christophe Cellier, Gabriel Rahmi

Gastroenterology and Digestive Endoscopy Department, Georges Pompidou European Hospital, AP-HP Centre - Université de Paris, Paris 


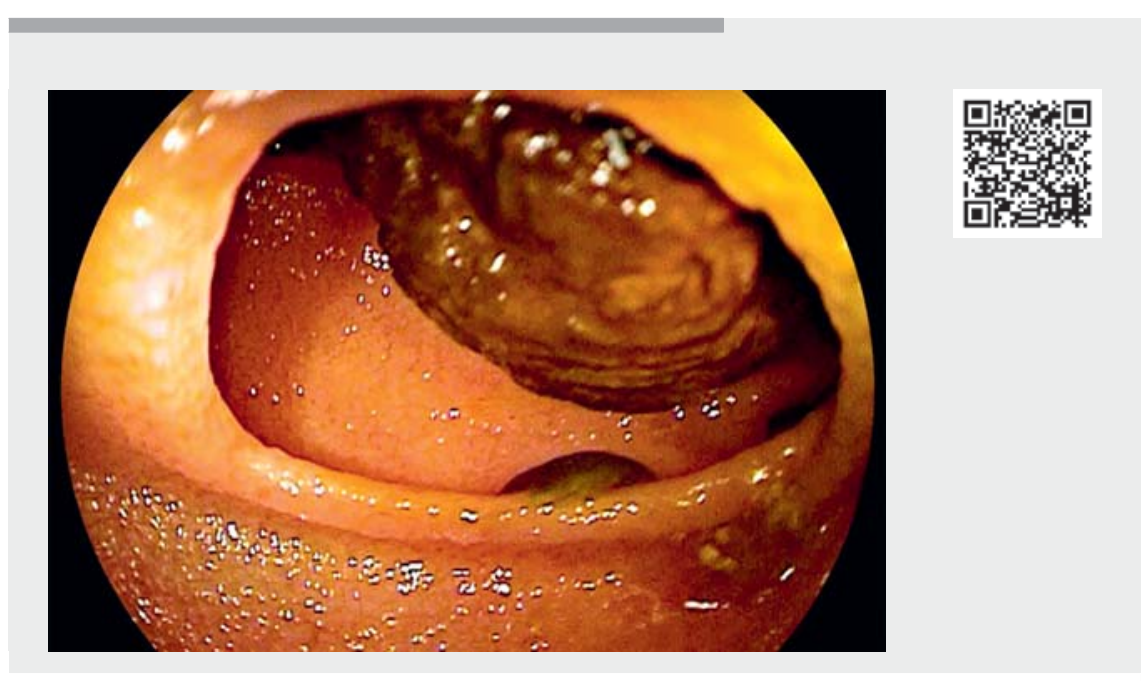

$\checkmark$ Video 1 An unusual cause of acute cholangitis.

\section{Corresponding author}

\section{Guillaume Perrod, MD}

Gastroenterology and Digestive Endoscopy Department, Georges Pompidou European Hospital, AP-HP Centre - Université de Paris, 20 Rue Leblanc, 75015 Paris

guillaume.perrod@aphp.fr

\section{References}

[1] Itokawa F, Itoi T, Ishii K et al. Single- and double-balloon enteroscopy-assisted endoscopic retrograde cholangiopancreatography in patients with Roux-en-Y plus hepaticojejunostomy anastomosis and Whipple resection. Dig Endosc 2014; 2: 136-143
Bibliography

Endoscopy 2022; 54: E314-E315

DOI 10.1055/a-1525-1824

ISSN 0013-726X

published online 9.7.2021

(c) 2021. Thieme. All rights reserved.

Georg Thieme Verlag KG, Rüdigerstraße 14 , 70469 Stuttgart, Germany

\section{ENDOSCOPY E-VIDEOS}

https://eref.thieme.de/e-videos

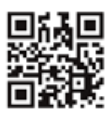

Endoscopy E-Videos is an open access online section, reporting on interesting cases and new techniques in gastroenterological endoscopy. All papers include a high quality video and all contributions are freely accessible online. Processing charges apply (currently EUR 375), discounts and wavers acc. to HINARI are available. without gastrectomy during endoscopic retrograde cholangiopancreatography using a short double-balloon enteroscope. Dig Endosc 2015; 27: 775

[3] Blanco-Velasco G, Blancas-Valencia JM, Hernández-Mondragón OV et al. Treatment of a bile duct leak with ERCP double-balloon enteroscopy in a patient with Roux-en-Y reconstruction. Endoscopy 2016; 48: E197E198

[4] Ebert EC, Nagar M, Hagspiel KD. Gastrointestinal and hepatic complications of sickle cell disease. Clin Gastroenterol Hepato 2010; 8: 483-489

[5] Manes G, Paspatis G, Aabakken L et al. Endoscopic management of common bile duct stones: European Society of Gastrointestinal Endoscopy (ESGE) guideline. Endoscopy 2019; 51: 472-491
This section has its own submission website at https://mc.manuscriptcentral.com/e-videos 